\title{
STUDI KANDUNGAN KROMIUM (Cr) PADA PERAKARAN TANAMAN BAKAU (Rhizophora stylosa) DI PERAIRAN SEKITAR TEMPAT PEMBUANGAN AKHIR (TPA) TELAGA PUNGGUR - BATAM
}

\section{THE STUDY OF THE CHROMIUM (Cr) CONTENT IN THE MANGROVE ROOTING (Rhizophora stylosa) AT TPA TELAGA PUNGGUR - BATAM}

\author{
Nurima Fauziah $^{1}$, Fenny Agustina $^{2}$, Notowinarto $^{2}$ \\ ${ }^{1}$ Alumni Program Studi Pendidikan Biologi, FKIP, Universitas Riau Kepulauan, Batam \\ ${ }^{2}$ Dosen Program Studi Pendidikan Biologi, FKIP, Universitas Riau Kepulauan, Batam
}

Koresponden: vennyagustina@gmail.com

\begin{abstract}
Abstrak
Penelitian ini bertujuan untuk mengidentifikasi akumulasi kandungan logam Chromium (Cr) di perakaran tanaman bakau Rhizophora stylosa yang tumbuh di sekitar perairan TPA Telaga Punggur dan Teluk Lengung Batam . Pengambilan sampel akar tanaman mulai dilakukan Februari - Mei 2013. diambil dari 4 (empat) titik plot untuk setiap pengamatan stasion. Hasil analisis laboratorium dari nilai akumulasi logam Chromium yang diperoleh bervariasi untuk setiap plot di stasiun pengamatan. Di stasiun TPA Telaga Punggur, petak 1 (946,95 mg / kg), petak $2(22,99 \mathrm{mg} / \mathrm{kg})$, petak $3(32,67 \mathrm{mg} / \mathrm{kg})$, dan plot 4 $(23,37 \mathrm{mg} / \mathrm{kg})$. Sementara di Stasiun Teluk Lengung, petak 1 (87,52 mg / kg), petak $2(27,19 \mathrm{mg} / \mathrm{kg})$, petak $3(28,43 \mathrm{mg} / \mathrm{kg})$, dan plot $4(22,85 \mathrm{mg} / \mathrm{kg})$. Analisis uji menggunakan Mann-Whitney menunjukkan bahwa $\mathrm{P}$ value $(0,8852)>\alpha(0,05)$ atau dengan uji rerata yakni $0,06 \mathrm{mg} / \mathrm{kg}$ menunjukkan bahwa tidak ada perbedaan akumulasi kandungan Chromium pada lokasi yang dekat outlet TPA Telaga Punggur dengan tanaman bakau yang berada di Teluk Lengung.
\end{abstract}

Kata Kunci: Chromium, Akar Rhizophora stylosa, TPA Telaga Punggur.

\begin{abstract}
This study aims to identify the accumulation of the metal content of Chromium $(\mathrm{Cr})$ in stylosa Rhizophora mangrove plant roots growing in the waters around the landfill TPA Telaga Punggur and the Gulf Lengung Batam. Sampling roots of the plant began in February-May 2013. taken from four (4) points for each observation station plot. Results of laboratory analysis of Chromium metal accumulation value obtained varies for each plot at the observation station. At the station of the landfill TPA Telaga Pungur followed; plot 1 (946.95 mg / kg), plot 2 (22.99 $\mathrm{mg} / \mathrm{kg})$, plot $3(32.67 \mathrm{mg} / \mathrm{kg}$ ), and the plot 4 $(23.37 \mathrm{mg} / \mathrm{kg})$, While in the Gulf Station Lengung, plot $1(87.52 \mathrm{mg} / \mathrm{kg})$, plot $2(27.19 \mathrm{mg} / \mathrm{kg})$, plot 3 $(28.43 \mathrm{mg} / \mathrm{kg})$, and the plot $4(22.85 \mathrm{mg} / \mathrm{kg})$, Analysis using the Mann-Whitney test showed that the P value (0.8852)> $\alpha(0.05)$ or with a test average of the $0.06 \mathrm{mg} / \mathrm{kg}$ showed no differences accumulated Chromium content at a location near the outlet of the landfill TPA Telaga Punggur with mangrove plants are located in the Gulf Lengung.
\end{abstract}

Keywords: Chromium, Roots of Rhizophora stylosa, TPA Telaga Punggur

\section{PENDAHULUAN}

Perairan sekitar Telaga Punggur kota Batam merupakan kawasan yang berdekatan dengan Tempat Pembuangan Akhir (TPA). TPA Telaga Punggur merupakan satusatunya tempat pembuangan akhir sampah yang terdapat di kota Batam. Sesuai UU nomor 18 tahun 2008 tentang pengelolaan sampah yang menyebutkan tempat 
pemprosesan akhir adalah tempat untuk memproses dan mengembalikan sampah ke media lingkungan secara aman bagi manusia dan lingkungan. Peraturan Pemerintah nomor 81 tahun 2012 tentang pengelolaan sampah rumah tangga dan sampah sejenis sampah rumah tangga Tempat Pemrosesan Akhir yang selanjutnya disingkat TPA adalah tempat untuk memproses dan mengembalikan sampah ke media lingkungan. Air lindi yang diketahui kandungan zat berbahaya sebelumnya berada di bak penampungan, namun tetap mengalir keluar menuju laut dan melewati pohon bakau yang berada tidak jauh dari lokasi (Rohman, 2013).

Kromium adalah unsur kimia yang secara alamiah ditemukan dalam konsentrasi yang rendah di batuan, hewan, tanaman, tanah, debu vulkanik dan juga gas. Kromium terdapat di alam dalam beberapa bentuk senyawa dalam bentuk kelat misalnya $\mathrm{Zn}$ EDTA. Kadar Zn dalam tanah berkisar $16-300 \mathrm{mg} / \mathrm{g}$ sedangkan kadar dalam tanaman 20-70 mg/g. Bentuk yang paling umum adalah Kromium (0), Kromium (III) dan Kromium (VI). Kromium (VI) dan Kromium (0) umumnya dihasilkan dari proses industri (Mengel dan Kirby, 1987).

Berdasarkan mekanisme fisiologis, mangrove secara aktif mengurangi penyerapan logam berat ketika konsentrasi logam berat di sedimen tinggi. Penyerapan tetap dilakukan, namun dalam jumlah yang terbatas dan terakumulasi di akar. Selain itu, terdapat sel endodermis pada akar yang menjadi penyaring dalam proses penyerapan logam berat (Baker dan Walker, 1990 dalam MacFarlane et al., 2003 dalam Arisandy $d k k$., 2012). Walaupun masukan sumber pencemar banyak, mangrove memiliki toleransi yang tinggi terhadap logam berat (Macfarlance dan Burchett, 2002). Hal ini menunjukkan bahwa mangrove secara aktif menghindari masukan logam berat berlebih dan juga berfungsi sebagai penyaring dan juga memiliki daya treatment khas secara alami melalui organ akar (Clark et al., 1998 dalam Kammaruzaman et al., 2008 ). Akumulasi logam berat terjadi pada akar dan dibawa ke jaringan lainnya dan proses ini membatasi masuknya udara ke dalam jaringan tersebut (Chiu dan Chou, 1991 dalam Macflarance et al., 2003).

Vegetasi mangrove dianggap sebagai spesies suksesi awal. Oleh karena itu kecendrungan untuk menyerap dan mengakumulasi logam-logam berat juga dimungkinkan terjadi pada ekosistem ini pada tanaman (Silvia et al., 1989 dalam Taryana, 1995). Akar merupakan organ yang kontak secara langsung dengan lingkungan, oleh karena itu akar merupakan suatu struktur dan berfungsi mengatur 
pengambilan dan transpor ion. Akar merupakan barrier utama terhadap pergerakan larutan ke dalam tumbuhan dan sebagai hasilnya konsentrasi ion yang diantarkan ke tunas sangat berbeda dari konsentrasi ion pada medium eksternal (Shannon et al., 1994 dalam Onrizal, 2005). Berdasarkan hal tersebut dapat dikemukakan tujuan dari penelitian yaitu adalah untuk mengetahui akumulasi atau jumlah kandungan logam Kromium pada perakaran Rhizophora stylosa di sekitar perairan TPA Telaga Punggur kota Batam.

\section{METODOLOGI}

Penelitian diawali dengan melakukan observasi lapangan di TPA Telaga Punggur secara langsung yang dilaksanakan pada tanggal 9 Februari 2013 dan penelitian inti akan dilaksanakan pada awal bulan Maret sampai dengan 13 Mei 2013. Pengambilan sampel akar diambil dari 2 lokasi, lokasi 1 (TPA Telaga Punggur) dan lokasi 2 (Teluk Lengung). Secara keseluruhan penelitian ini terdiri atas 5 tahap, diantaranya : (1) Tahap persiapan (survey lapangan dan wawancara pihak TPA Telaga Punggur), (2) Tahap sampling (pengambilan sampel), (3) Tahap analisis sampel, (4) Tahap pengumpulan data, dan (5) Tahap analisis data.

Data kandungan Kromium di kedua lokasi pada perakaran Rhizophora stylosa dianalisis dengan menggunakan analisis nonparametrik Mann-Whitney, dan untuk menguji dugaan median kandungan Kromium pada penelitian sebelumnya menurut Jiao et al. (1997) menggunakan analisis statistik Uji-tanda.

\section{PEMBAHASAN}

Merujuk pada Kepmen Negara Lingkungan Hidup tentang baku mutu untuk mendukung kehidupan biota laut adalah berkisar antara $28^{\circ} \mathrm{C}$ sampai $32^{\circ} \mathrm{C}$. Sehingga dapat dikatakan suhu di perairan Stasiun I (TPA Telaga Punggur) dan Stasiun II (Teluk Lengung) masih mendukung kehidupan Biota laut di kedua lokasi tersebut.

Dalam mendukung fisiologi dan respirasinya, Rhizophora stylosa memiliki kriteria suhu optimal adalah $26^{\circ} \mathrm{C}$ sampai $28^{\circ} \mathrm{C}$. Tingginya suhu di Stasiun I disebabkan di lokasi tersebut merupakan lokasi yang berdekatan dengan outlet bak lindi, diketahui bak lindi menggunakan bakteri untuk proses fermentasi. Namun, suhu yang melebihi $30^{\circ} \mathrm{C}$ menyebabkan pembusukan pada tanaman (Lawson, 2011). Pada bak lindi suhu mencapai $33,8^{\circ} \mathrm{C}$ karena adanya aktifitas bakteri anaerob. Perubahan suhu berpengaruh 
terhadap proses fisika, kimia dan biologi badan air. Peningkatan suhu juga menyebabkan peningkatan kecepatan metabolisme dan respirasi organisme air, dan selanjutnya mengakibatkan peningkatan konsumsi oksigen (Effendi, 2003).

Tabel 1. Hasil Pengukuran Kualitas Air pada Kedua Stasiun Pengamatan

\begin{tabular}{clcccc}
\hline \multirow{2}{*}{ NO } & \multirow{2}{*}{ PARAMETER } & \multirow{2}{*}{$\begin{array}{c}\text { OUTLET BAK } \\
\text { LINDI }\end{array}$} & \multicolumn{2}{c}{ MANGROVE } & \multirow{2}{*}{ BAKU MUTU } \\
\cline { 4 - 5 } & & 33,8 & 32,09 & 32,4 & $28-32$ \\
\hline 1 & Suhu $\left({ }^{\circ} \mathrm{C}\right)$ & 8,65 & 7,8 & 7,58 & $7-8.5$ \\
2 & $\mathrm{pH}$ & 3 & 21 & 18 & $\mathrm{~s} / \mathrm{d} 34$ \\
3 & Salinitas (ppt) & 1,05 & 3,57 & 0,73 & $>5$ \\
\hline
\end{tabular}

*) Baku mutu berdasarkan Kepmen-LH 51 Tahun 2004 (Untuk Biota Laut).

Dalam mendukung fisiologi dan respirasinya, Rhizophora stylosa memiliki kriteria suhu optimal adalah $26^{\circ} \mathrm{C}$ sampai $28^{\circ} \mathrm{C}$. Tingginya suhu di Stasiun I disebabkan di lokasi tersebut merupakan lokasi yang berdekatan dengan outlet bak lindi, diketahui bak lindi menggunakan bakteri untuk proses fermentasi. Namun, suhu yang melebihi $30^{\circ} \mathrm{C}$ menyebabkan pembusukan pada tanaman (Lawson, 2011). Pada bak lindi suhu mencapai $33,8^{\circ} \mathrm{C}$ karena adanya aktifitas bakteri anaerob. Perubahan suhu berpengaruh terhadap proses fisika, kimia dan biologi badan air. Peningkatan suhu juga menyebabkan peningkatan kecepatan metabolisme dan respirasi organisme air, dan selanjutnya mengakibatkan peningkatan konsumsi oksigen (Effendi, 2003).

Derajat Keasaman $(\mathrm{pH})$ mempengaruhi toksisitas suatu senyawa kimia, sebagian besar biota akuatik sensitif terhadap perubahan $\mathrm{pH}$ dan menyukai nilai $\mathrm{pH}$ sekitar 7 sampai 8,5. Nilai $\mathrm{pH}$ sangat mempengaruhi proses biokimiawi perairan, misalnya proses nitrifikasi akan berakhir jika $\mathrm{pH}$ rendah. Toksisitas logam memperlihatkan peningkatan pada pH rendah (Novotny dan Olem, 1994 dalam Effendi, 2003). Namun demikian, pH di Stasiun I (TPA Telaga Punggur) dan Stasiun II (Teluk Lengung) masih berada pada standar baku mutu menurut Kepmen Negara Lingkungan Hidup nomor 51 tahun 2004 yaitu $7-8,5$. Sehingga dapat dikatakan $\mathrm{pH}$ di perairan tersebut masih mendukung kehidupan Biota laut. Nonjti (1993) menyebutkan bahwa salinitas dipengaruhi oleh berbagai faktor seperti sirkulasi air, penguapan, curah hujan, dan aliran sungai. Kepmen Negara Lingkungan Hidup nomor 51 tahun 2004 yaitu baku mutu minimal di perairan 
mangrove untuk mendukung kehidupan biota laut adalah sampai dengan 34 ppt. Sehingga, salinitas di kedua lokasi tersebut masih mendukung kehidupan biota laut.

Menurut Effendi (2003) Kadar oksigen terlarut berfluktuasi secara harian (diurnal) dan musiman, tergantung pada pencampuran (mixing) dan pergerakan (turbelence) massa air, aktivitas fotosintesis, respirasi, dan limbah (effluent) yang masuk ke badan air. Dan didukung oleh Jeffries dan Mills (1996) dalam Effendi (2003). Oksigen merupakan salah satu gas yang terlarut dalam perairan. Kadar oksigen yang terlarut di perairan alami bervariasi, tergantung pada suhu, salinitas, tubelensi (altitude) serta semakin kecil tekanan atmosfer, maka kadar oksigen terlarut semakin kecil.

Batas minimal oksigen terlarut untuk mendukung kehidupan biota laut adalah $>5$ mg/L, sehingga kadar oksigen terlarut pada Stasiun I (TPA Punggur) dan Stasiun II (Teluk Lengung) dapat dikatakan tidak mendukung kehidupan biota laut di kedua lokasi tersebut.

Tabel 2. Kandungan Logam Berat dalam Perairan TPA Telaga Punggur dan Teluk Lengung

\begin{tabular}{|c|c|c|c|c|c|}
\hline NO & PARAMETER & SATUAN & $\begin{array}{c}\text { ST.TPA } \\
\text { PUNGGUR }\end{array}$ & $\begin{array}{l}\text { ST. TELUK } \\
\text { LENGUNG }\end{array}$ & $\left.\mathbf{B} \mathbf{M}^{*}\right)$ \\
\hline 1 & Raksa (Hg) • & $\mathrm{mg} / \mathrm{L}$ & $<0,0002$ & $<0,0002$ & 0,001 \\
\hline 2 & $\operatorname{Kromium}(\mathrm{Cr}) \bullet$ & $\mathrm{mg} / \mathrm{L}$ & $<0,001$ & 0,023 & 0,005 \\
\hline 3 & $\operatorname{Arsen}(\mathrm{As}) \cdot$ & $\mathrm{mg} / \mathrm{L}$ & $<0,0002$ & $<0,0002$ & 0,012 \\
\hline 4 & $\operatorname{Kadmium}(\mathrm{Cd}) \bullet$ & $\mathrm{mg} / \mathrm{L}$ & $<0,001$ & $<0,001$ & 0,001 \\
\hline 5 & Timbal $(\mathrm{Pb}) \cdot$ & $\mathrm{mg} / \mathrm{L}$ & $<0,005$ & $<0,005$ & 0,008 \\
\hline 6 & Tembaga $(\mathrm{Cu}) \bullet$ & $\mathrm{mg} / \mathrm{L}$ & 0,012 & $<0,005$ & 0,008 \\
\hline 7 & Seng $(\mathrm{Zn}) \cdot$ & $\mathrm{mg} / \mathrm{L}$ & 0,005 & $<0,005$ & 0,05 \\
\hline
\end{tabular}

*) Baku mutu berdasarkan Kepmen-LH 51 Tahun 2004 (untuk Biota Laut).

Dari paparan diatas, kadar atau kandungan dari semua parameter logam berat yang terdeteksi pada Stasiun I dan Stasiun II masih tergolong kecil, kecuali logam $\mathrm{Cu}$ yang terdapat pada perairan Stasiun I dan logam Cr yang terdeteksi pada Stasiun II. Hal ini disebabkan, pada proses pengambilan sampel air di stasiun I (TPA Telaga Punggur) dan stasiun II (Teluk Lengung) dilakukan pada saat musim hujan. Didukung oleh Darmono (1995), menyebutkan bahwa logam dalam air berbentuk ion, kandungan logam dalam air dapat berubah-ubah dan sangat tergantung pada lingkungan dan iklim. Pada musim hujan, kandungan logam akan lebih kecil karena proses pelarutan, sedangkan pada musim kemarau kandungan logam dalam air akan lebih tinggi karena logam menjadi terkonsentrasi, namun kandungan logam dalam organisme air akan selalu bertambah dari waktu ke waktu karena sifat logam yang bioakumulatif. 
TPA Telaga Punggur merupakan lokasi yang memiliki kandungan Kromium tertinggi khususnya pada plot $1(946,95 \mathrm{mg} / \mathrm{kg})$, kondisi tersebut disebabkan posisi Stasiun I yang terletak berdekatan dengan outlet bak lindi dan kondisi wilayah sampling tersebut berlumpur dan bersubstrat dalam, dengan menghasilkan sedimen yang banyak. Didukung oleh Jiao et al. (1997) bahwa mangrove memberikan pengaruh yang penting terhadap penurunan kontaminasi di tanah. Adanya pembuangan limbah di sekitar estuari wilayah vegetasi mangrove menyebabkan peningkatan konsentrasi logam di sedimen. Karena pada saat proses sedimentasi, unsur nutrien bergabung dengan logam yang juga ikut tersuspensi di dalam sedimen.

Tabel 3. Kandungan Kromium pada Perakaran Rhizophora stylosa di TPA Telaga Punggur dan Teluk Lengung

\begin{tabular}{|c|c|c|c|c|c|c|}
\hline \multirow{2}{*}{$\begin{array}{l}\text { WILAYAH } \\
\text { SAMPLING }\end{array}$} & \multicolumn{4}{|c|}{$\begin{array}{l}\text { KANDUNGAN KROMIUM (mg/kg) } \\
\text { PLOT }\end{array}$} & \multirow[t]{2}{*}{$\sum$} & \multirow{2}{*}{$\overline{\mathbf{x}}$} \\
\hline & 1 & 2 & 3 & 4 & & \\
\hline Stasiun I & 946,95 & 22,99 & 32,37 & 23,37 & 1025,98 & 256,495 \\
\hline Stasiun II & 87,52 & 27,19 & 28,43 & 22,85 & 165,99 & 41,4975 \\
\hline
\end{tabular}

Dari data yang diperoleh terlihat bahwa akumulasi Kromium dalam akar mangrove di Stasiun I sangat besar. Hal ini menunjukkan Rhizophora stylosa cukup efektif dalam menyerap logam berat dari substrat. Akumulasi logam yang terlalu tinggi akan menyebabkan toksik bagi tanaman. Sejumlah logam berat dapat berkombinasi dengan membran sel, aktivitas yang paling tinggi kebanyakan logam-logam berat terhadap sulfur. Seperti diketahui protein mempunyai satu atau lebih unit molekul asam amino, sistem yang mengandung sulfur. Jembatan disulfida penting dalam hal memberikan bentuk terhadap protein dan logam berat dapat merubah ikatan sulfur disulfida. Sebagai contoh ion metyl merkuri $\left(\mathrm{CH}_{3}-\mathrm{Hg}^{+}\right)$dapat bergabung dengan protein dan dapat membentuk molekul baru dalam bentuk protein-S-Hg- $\mathrm{CH}_{3}$. Proses-proses kimia tersebut merupakan bahaya utama adanya pencemaran logam berat dan jika suatu organisme proteinnya berubah, maka organisme tersebut dapat cepat mati (Team Kualitas Air PPSL, 1979 dalam Taryana 1995). Sedangkan kandungan terendah dari logam Kromium oleh Stasiun II khususnya pada plot empat $(22,85 \mathrm{mg} / \mathrm{kg})$, disebabkan karena posisi Stasiun II terletak berjauhan dari sumber cemaran logam yaitu outlet bak lindi TPA Telaga Punggur.

Analisis perbandingan dalam penelitian ini menggunakan uji perbandingan yang bersifat non parametrik. Analisis non parametrik digunakan untuk data yang diasumsi 
tidak normal. Analisis perbandingan non parametrik dalam penelitian ini menggunakan 2 uji perbandingan yaitu Uji Mann-whitney dan uji tanda. Uji Mann-whitney untuk membandingkan kadar logam Kromium di akar Rhizophora stylosa Stasiun I dengan kadar logam di akar Stasiun II. Uji tanda digunakan untuk menguji median yang bertujuan mengukur kadar logam Kromium di akar Rhizophora stylosa Stasiun I dengan Stasiun II dengan penelitian sebelumnya, yaitu dengan test median $(0,06 \mathrm{mg} / \mathrm{kg})$.

Uji Mann-Whitney (nonparametrik) merupakan alternatif bagi uji-t (parametrik). Uji Mann-Whitney adalah uji non-parametrik yang digunakan untuk membandingkan dua mean populasi yang berasal dari populasi yang sama dan tidak terdistribusi normal. Populasi yang akan diuji mengunakan uji Mann-Whitney yaitu kandungan logam Kromium di perakaran Rhizophora stylosa Stasiun I (TPA Telaga Punggur) dengan Stasiun II (Teluk Lengung). Adapun hipotesis yang digunakan dalam uji Mann-whitney adalah bahwa level tolerensi $(\alpha)$ ditetapkan adalah 0.05 , daerah penenolakan $\mathrm{H}_{0}$ apabila $\mathrm{P}_{\text {value }}<\alpha$. Berdasarkan hasil uji Mann Whitney didapatkan bahwa $\mathrm{P}_{\text {value }}$ yang didapatkan sebesar 0.8852. Dengan tolerensi 5\% (0.05) maka $\mathrm{H}_{0}$ diterima, sehingga dapat disimpulkan bahwa tidak ada beda akumulasi logam Kromium antara Stasiun I (TPA Telaga Punggur) dan Stasiun II (Teluk Lengung).

Uji tanda digunakan untuk menguji dugaan median suatu populasi berdistribusi kontinyu. Uji tanda disebut juga uji lokasi karena median merupakan salah satu ukuran pemusatan. Untuk mendapatkan perbandingan antara akumulasi Kromium di akar Rhizophora stylosa di Stasiun I dan Stasiun II dengan median 0,06 mg/kg. Hipotesis yang ditetapkan adalah level tolerensi $(\alpha)$ ditetapkan adalah 0.05 , daerah penolakan $\mathrm{H}_{0}$ apabila $\mathrm{P}_{\text {value }}<\alpha$. Dari analisis didapatkan bahwa $\mathrm{P}_{\text {value }}$ sebesar 0,1250 sedangkan nilai $\alpha$ yaitu 0,05 . Karena $\mathrm{P}_{\text {value }}>\alpha$, maka $\mathrm{H}_{0}$ diterima, sehingga akumulasi logam Kromium yang terdapat pada perakaran Rhizophora stylosa di Stasiun I dengan Stasiun II melebihi $0,06 \mathrm{mg} / \mathrm{kg}$.

\section{KESIMPULAN}

Dari hasil penelitian yang telah dilakukan terhadap kandungan Kromium pada akar Rhizophora stylosa di perairan sekitar TPA Telaga Punggur Kota Batam, dapat diambil kesimpulan bahwa pada Perairan Stasiun I memiliki akumulasi kandungan logam berat $\mathrm{Cu}(0,012 \mathrm{mg} / \mathrm{L})$ kadar tersebut sudah di atas baku mutu. Sedangkan di 
Perairan Stasiun II memiliki kandungan logam berat Cr $(0,023 \mathrm{mg} / \mathrm{L})$ kadar tersebut juga berada di atas standar baku mutu. Sehingga dapat disimpulkan perairan TPA Telaga Punggur dan Teluk Lengung sudah tercemar oleh logam berat dan tidak mendukung kehidupan biota laut. Hasil analisis uji Mann-Whitney menunjukkan bahwa tidak ada perbedaan akumulasi antara Stasiun I di perairan TPA Telaga Punggur dan Stasiun II di perairan Teluk Lengung. Hasil analisis Uji-Tanda menunjukkan bahwa akumulasi logam Kromium di perakaran melebihi dari median 0,06 mg/kg (0,06 mg/kg adalah kandungan Kromium pada akar Rhizophora stylosa menurut Jiao et al. (1997).

\section{REFERENSI}

Arisandy, K.R., E.Y. Herawati, dan E. Supriyatno. 2012. Jurnal: Akumulasi Logam Berat Timbal $(\mathrm{Pb})$ dan Gambaran Histologi pada Jaringan Avicennia marina (forsk.) Vierh di Perairan Pantai Jawa Timur. Fakultas Perikanan dan Ilmu Kelautan Universitas Brawijaya, Malang.

Darmono. 1995. Logam Dalam Sistem Biologi Makhluk Hidup. Universitas Indonesia (UI-Press), Jakarta.

Darmono. 2001. Lingkungan hidup dan Pencemaran: Hubungannya dengan Toksikologi Senyawa Logam. Universitas Indonesia Press, Jakarta.

Effendi, H. 2003. Telaah Kualitas Air Bagi Pengelolaan Sumberdaya dan Lingkungan Perairan. Penerbit Kanisius, Yogyakarta.

Jiao, W.Z., C.X. Chen and L. Peng. 1997. Journal : Accumulation and Biological Cycling of Heavy Metal Elements in Rhizophora stylosa Mangroves in Yingluo Bay. Marine Ecology Progress Series. Republic of China.

Kammaruzaman, B.Y., M.C. Ong., K. C. A. Jalal., S. Shahbudin, dan O. M. Nor. 2008. Accumulation of Lead and Copper in Rhizophora apiculata from Setiu Mangrove Forest. Terenggaru, Malaysia.

Kepmen LH Nomor 51 Tahun 2004. Baku Mutu Air Laut.

Kustanti, A. 2011. Manajemen Hutan Mangrove. IPB Press, Bogor.

Macfarlance, G.R., M.D. Burchett. 2002. Toxicity, Growth and Accumulation Relationships of Copper, Lead and Zinc in the Grey Mangrove, Avicennia Marina (forsk) Vierh. Aquatic Botany.

Macflarance, G.R., Pulkownik and M.D. Burchett. 2003. Accumulation and Distribution of Heavy Metals in grey Mangrove, Avicennia marina (forsk) vierh: Biological Indication Potential. Enviromental Pollution. 
SNI 6989 17. 2009. Cara uji Kromium (Cr) secara Spektrofotometri Serapan Atom (SSA)-nyala

Taryana, A.T. 1995. Jurnal: Akumulasi Logam Berat (Cu, Mn, Zn) pada Jenis Rhizophora stylosa Griff. Di Hutan Tanaman Mangrove Cilacap BKPH Rawa Timur KPH Banyumas Barat Perum Perhutani Unit I Jawa Tengah. Institut Pertanian Bogor, Bogor. 